\title{
A Structural $V_{\mathrm{P}}$ Model of the Salton Trough, California, and Its Implications for Seismic Hazard
}

\author{
by Peter Lovely, John H. Shaw, Qinya Liu, and Jeroen Tromp
}

\begin{abstract}
We present a high-resolution, three-dimensional $P$-wave seismic velocity model of the sedimentary basin in the Salton Trough, southern California, and use the model for spectral-element method (SEM) wave propagation and groundmotion simulations to quantitatively assess seismic hazard in the region. The basin geometry is defined by a surface representing the top of crystalline basement, which was constrained by seismic refraction profiles and free-air gravity data. Sonic logs from petroleum wells in the Imperial Valley and isovelocity surfaces defined by seismic refraction studies were used to define $P$-wave velocity within the sedimentary basin as a function of two variables:(1) absolute depth and (2) depth of the underlying crystalline basement surface (CBS). This velocity function was used to populate cells of a three-dimensional spatial array (voxet) defining the $P$-wave velocity structure in the basin. The new model was then resampled in a computational mesh used for earthquake wave propagation and strong ground motion simulations based upon the SEM (Komatitsch et al., 2004). Simulation of the 3 November $2002 M_{\mathrm{w}} 4.2$ Yorba Linda earthquake demonstrates that the new model provides accurate simulation of strong ground motion amplification effects in the Salton Trough sedimentary basin, offering substantial improvements over previous models. A hypothetical $M_{\mathrm{w}} 7.9$ earthquake on the southern San Andreas fault was then simulated in an effort to better understand the seismic hazard associated with the basin structure. These simulations indicate that great amplification will occur during large earthquakes in the region due to the low seismic velocity of the sediments and the basin shape and depth.
\end{abstract}

Online material: Details of the gravity modeling techniques.

\section{Introduction}

Accurate earthquake hazard assessment is of tremendous importance in southern California due to its large and rapidly growing population, coupled with high rates of seismicity along faults that define the tectonically active PacificNorth American plate boundary. In recent years, threedimensional wave-propagation modeling and strong ground motion simulations have become an increasingly important part of seismic hazard assessment, as better models, rapid advances in computing power, and improved numerical methods have enabled more accurate simulations. These simulation techniques include finite-difference (e.g., Boore, 1972; Frankel and Leith, 1992; Frankel and Vidale, 1992; McLaughlin and Day, 1994; Olsen et al., 1995; Antolik et al., 1996; Pitarka and Irikura, 1996; Larsen et al., 1997; Kristek et al., 1999; Stidham et al., 1999; Ji et al., 2000; Satoh et al., 2001; Minster et al., 2004) and finite-element methods (e.g., Lysmer and Drake, 1972; Bao et al., 1998; Bielak et al., 1999; Garatani et al., 2000; Aagaard et al.,
2001). Furthermore, Komatitsch et al. (2004) demonstrated that numerical simulations employing the spectral-element method (SEM) were capable of accurately modeling strong ground motions at moderate to long periods $(2$ to $6 \mathrm{sec})$ in southern California for the purpose of seismic hazard assessment.

Accurate numerical simulations increasingly depend upon accurate three-dimensional regional models of material properties. The spectral-element method (SEM) computation employed by Komatitsch et al. (2004) relies upon a threedimensional mesh defining the $P$-wave and $S$-wave velocities and density structure of the region being modeled. Komatitsch et al. (2004) based their mesh on the highresolution Harvard Los Angeles Basin velocity model (Süss and Shaw, 2003), which was embedded in a low-resolution regional tomography model (Hauksson, 2000). The combination of these two models produced an accurate quantitative representation of ground motion throughout the region, par- 
ticularly the amplification effects of the low-velocity sediments in the Los Angeles basin.

Simulation results in the Salton Trough, however, remained of poor quality as illustrated in the transverse component displacement seismograms in Figure 1. Presumably, these poor results were caused by the regional tomographic model's failure to provide a precise representation of the structure and low seismic velocities in the basin, which have the potential to amplify ground motions by a factor of 4 or more (Komatitsch et al., 2004; Liu et al., 2004). Though the population of the Salton Trough is modest compared with
Los Angeles, accurate seismic hazard assessment is important here as well. Imperial County, which encompasses most of the portion of the Salton Trough in the United States, has a significant population and was the third fastest growing county in California from 1990 to 2000 (State of California Department of Finance, 2000). Furthermore, the city of Mexicali, just south of the U.S.-Mexican border, is the capital of the Mexican state of Baja California and has a population of 850,000 . Mexicali also is growing rapidly, with a conservative estimate placing its population at over 1.2 million by 2020 (Wright et al., 1998).

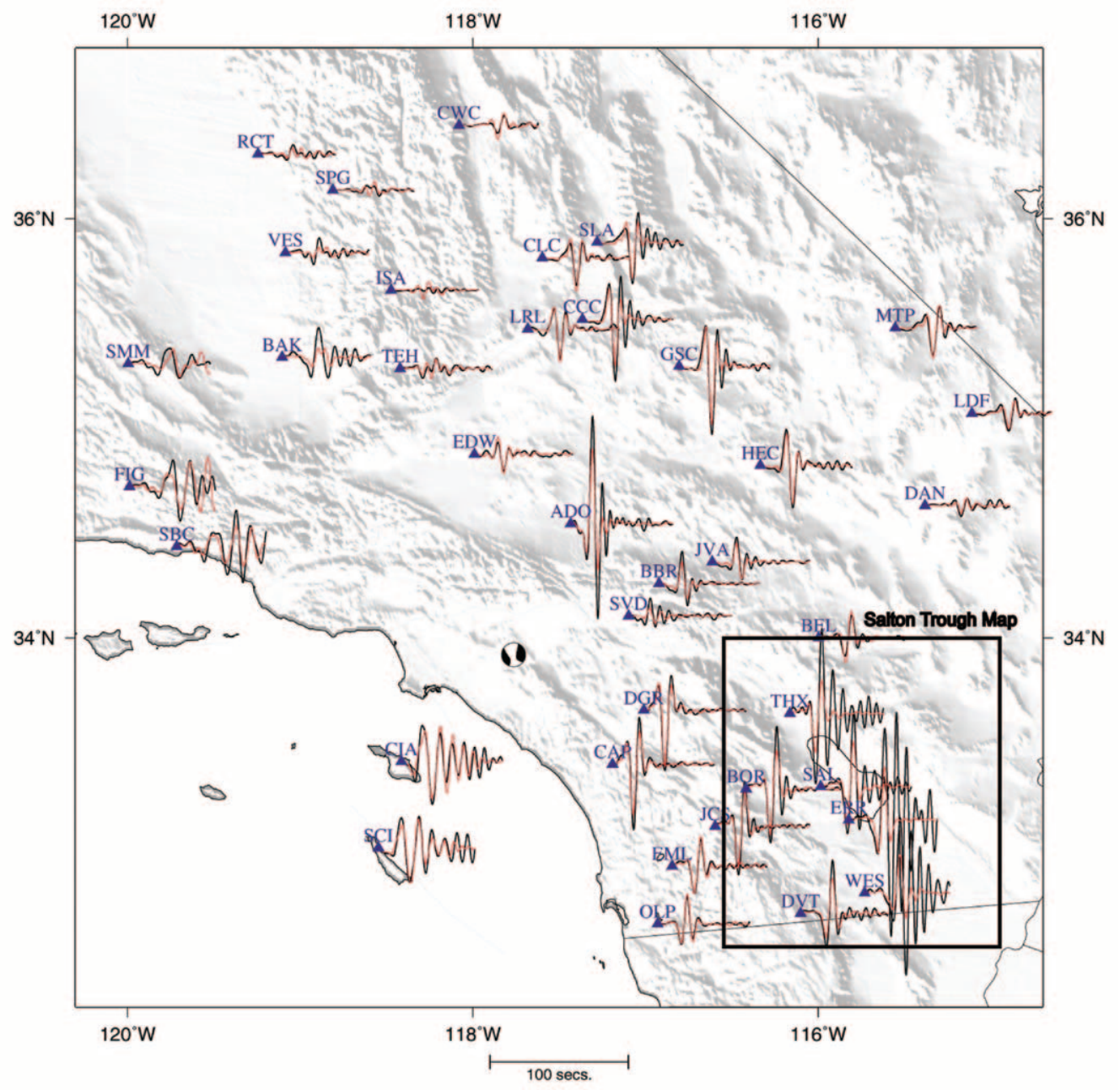

Figure 1. Regional map showing the transverse component of displacement seismograms at select stations throughout Southern California from the 3 September 2002 $M_{\mathrm{w}} 4.2$ Yorba Linda earthquake. Transverse component seismograms were selected for figures because of the predominantly strike-slip earthquakes treated in our simulations. Strike-slip events excite the greatest energy on the transverse component. Black waveforms represent recorded data, and red waveforms represent synthetic data produced by the SEM computations of Komatitsch et al. (2004) using a high resolution Los Angeles Basin velocity model (Süss and Shaw, 2003) embedded in a lower resolution regional tomography model (Hauksson, 2000). Both the data and the synthetic seismograms were subsequently bandpass filtered between 6 and $35 \mathrm{sec}$ with a four-pole two-pass butterworth filter. This figure illustrates that, with the exception of the Salton Trough, this technique produces accurate wave propagation and strong ground motion simulations throughout the region. The black box outlines the Salton Trough region represented in Figure 8. 
The Salton Trough is historically one of the most seismically active regions in California. The San Andreas fault, proper, terminates near the northern end of the Salton Sea, but right-lateral strike-slip seismicity continues to the south, accommodated by the Brawley seismic zone and Imperial fault (Hill et al., 1991). The San Jacinto and Elsinore fault systems lie to the west (Fig. 2). Together the Elsinore, San Jacinto, and San Andreas fault zones accommodate approximately $50 \mathrm{~mm}$ of right-lateral slip per year, (Rockwell and Sylvester, 1979) posing significant seismic hazard in the Salton Trough. Furthermore, the San Andreas fault southwest of Lancaster, California, is thought to be building toward what could be a large rupture (Weldon et al., 2004). With the southern end of the fault system extending into the Salton Trough, a rupture here would likely focus a great deal of energy into the trough, where ground motion would be amplified by the low-velocity sediments. The devastating effects of basin amplification have been observed and recorded in many historic earthquakes, including the 1 October 1987 $M_{\mathrm{w}} 6.1$ Whittier Narrows and the 17 January $1994 M_{\mathrm{w}} 6.7$
Northridge earthquakes near Los Angeles (Hruby and Beresnev, 2003), as well as the 17 October $1989 M_{\mathrm{w}} 6.9$ Loma Prieta earthquake near San Francisco (Borcherdt, 1994). In part to address this concern, the SCEC sponsored TeraShake project (Minster et al., 2004) simulated such a large earthquake on the southern San Andreas fault highlighting that large amplifications are expected to occur in the Salton Trough. However, these simulations lacked a precise description of the basin structure, which is needed to reliably quantify the anticipated strong ground motions.

In an effort to more accurately assess seismic hazards in the Salton Trough, we have produced a new $P$-wave seismic velocity model to represent the sedimentary basin in this region. This model is incorporated into a computational mesh used for spectral-element simulations of the 3 November $2002 M_{\mathrm{w}} 4.2$ Yorba Linda earthquake (Komatitsch et al., 2004), yielding significantly improved ground-motion simulation results in the Salton Trough. Further simulation efforts were then focused on a hypothetical southern San Andreas fault rupture to assess the ground-motion hazards posed by

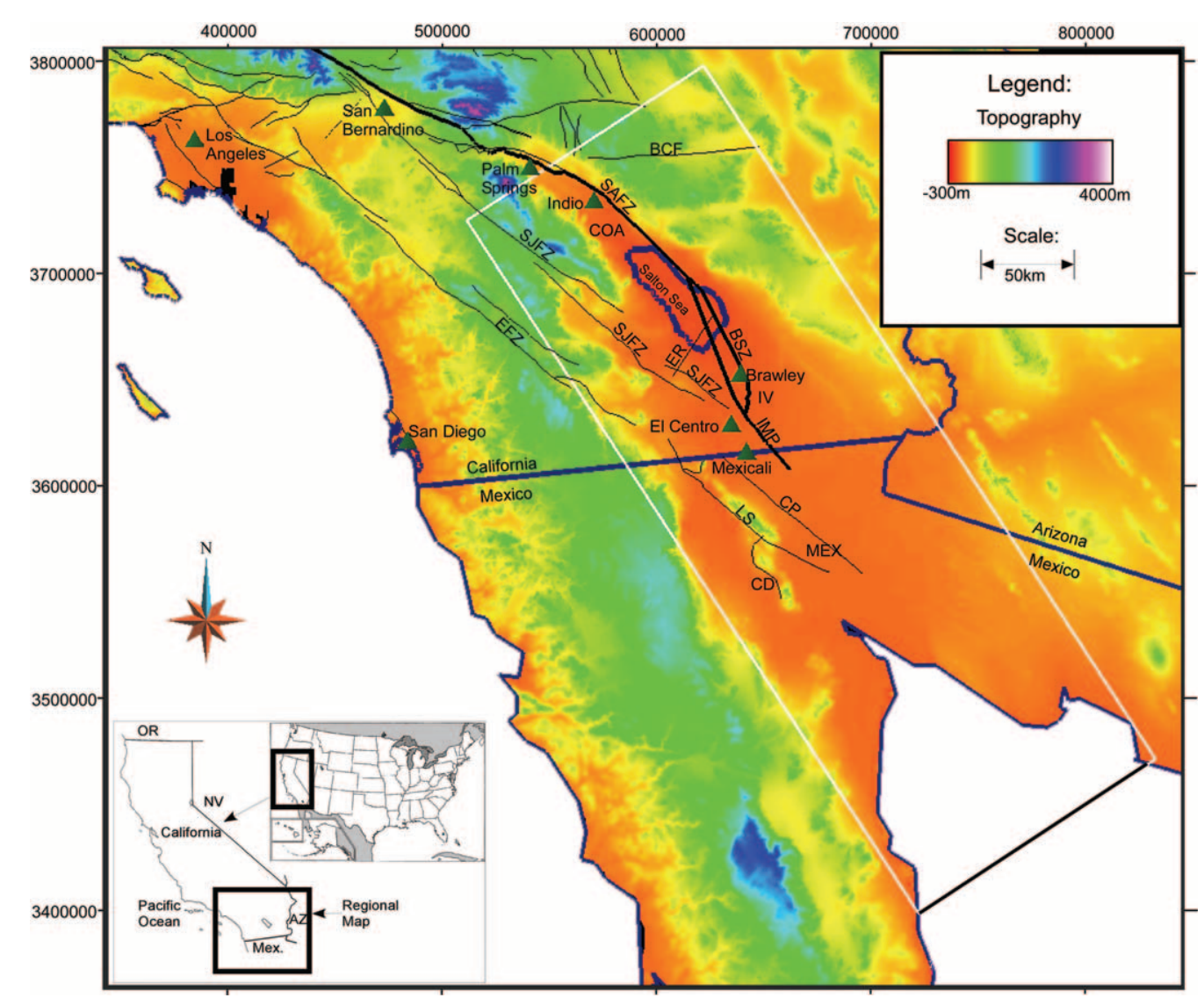

Figure 2. Map of the boundaries of the Salton Trough $P$-wave velocity model (white box). Color denotes topography, and surface traces of major faults are represented in black, with the San Andreas fault bold. Population centers in the Salton Trough and major cities in the region are represented by green triangles. Key to abbreviations: SAF, San Andreas fault; BSZ, Brawley seismic zone; IMP, Imperial fault; SJFZ, San Jacinto fault zone; ER, Elmore Ranch fault; CP, Cerro Prieto; LS, Laguna Salada; CD, Cañada David detachment; EFZ, Elsinore Fault Zone; BCF, Blue Cut Fault; COA, Coachella Valley; IV, Imperial Valley; MEX, Mexicali Valley. 
large earthquakes given our improved understanding of the basin structure.

\section{Geologic Setting}

The Salton Trough lies along the Pacific-North American plate boundary, at the juncture between the San Andreas fault system to the north and a series of transform faults joined by short spreading ridges in the Gulf of California to the south (Terres and Crowell, 1979). The trough is often considered a northern continuation of the Gulf of California extensional environment, isolated from the gulf's marine environment only by the sediments of the Colorado River Delta (Schmidt, 1990).

The Salton Trough is a deep and elongate sedimentary basin typically divided into three geographic regions: the Mexicali Valley south of the U.S.-Mexico border, the Imperial Valley between the international border and the Salton Sea, and the Coachella Valley north of the Salton Sea. The basin is characterized by a steep thermal gradient (Lachenbruch et al., 1985; Paillet et al., 1986) and a shallow Moho (Magistrale et al., 2000), resulting from the extensional tectonics in the region. Sediments in the trough may be as deep as $15 \mathrm{~km}$, but below approximately $6 \mathrm{~km}$ the temperature is high enough that rocks undergo metamorphism (Fuis and Mooney, 1991). This metamorphosed material exhibits properties more similar to crystalline basement than sedimentary rock and thus is generally considered crystalline basement, as it is in this article.

\section{$V_{\mathrm{p}}$ Modeling Method}

\section{Crystalline Basement Surface Definition}

The first step in creating the $P$-wave velocity model was to define the geometry of the basin. A geological crystalline basement surface was generated that defines the interface between the sediments of the basin and the metamorphosed or otherwise crystalline rocks outside the basin. A surface of this nature was previously defined in part of the Imperial Valley by Fuis and Kohler (1984). Its map coverage is illustrated in Figure 3. We extended this surface laterally to encompass the whole of the Salton Trough sedimentary basin using surface geology, wells, and the free-air gravitational field (Sandwell and Smith, 1997; Lemoine et al., 1998).

Seven transects for two-dimensional gravity modeling were defined across the trough perpendicular to its axis. The two transects crossing the basement surface defined by Fuis and Kohler (1984) were modeled, demonstrating that basin geometry and topography are the two main features strongly affecting the gravitational field in the region (Lovely, 2005). The GTOPO30 (USGS, 2000) dataset was used for modeling topography. These two transects were then used to calibrate the model with appropriate density contrasts. Two-dimensional representations of basin geometry were then determined across the other transects, and an extended surface was produced by interpolation between these twodimensional profiles and a crystalline basement surface on a seismic refraction profile along the trough axis from Biehler (1964). The complete basement surface is shown in Figure 4. (E) Gravity profiles and models are available online in the electronic edition of BSSA.)

\section{Velocity Parameterization}

The velocity structure of the basin was determined using sonic logs from petroleum wells in the Imperial Valley and from a seismic refraction study in the region published by Fuis et al. (1984). The locations of well and refraction data are illustrated in Figure 3. Sonic logs are direct measurements of interval transit time between a source and receiver on opposite ends of a logging tool and provide measures of the $P$-wave velocity under lithostatic pressure. These data are typically used in the petroleum industry to determine porosity, density, and lithology. The distance between source and receiver is typically small (1-2 m), and the tool is moved along the borehole, recording continuously. The transmitter emits in a sonic-to-ultrasonic range, and the receiver records $P$-wave arrivals. The resulting sample resolution is $\sim 60 \mathrm{~cm}$. Measurements record interval transit times, which are directly converted to interval velocities. Based on the needs of our model, sonic log measurements were scaled to approximately 2-m samples using the method of Süss and Shaw (2003).

The sonic log data show that seismic velocities increase with depth in a roughly linear manner, as is observed in many sedimentary basins. Moreover, we noted that isovelocity horizons from Fuis et al. (1984) tend to shallow toward the basin edges. This suggests that the velocity gradient with depth steepens toward the basin edges. Thus, we chose to define velocity in our model as a linear function of absolute depth in which the velocity gradient varies with total basin depth. This approach was preferred over a model based on geostatistical interpolation (e.g., Süss and Shaw, 2003) given that the data in the Salton Trough is sparse and its extent is largely limited to the Imperial Valley. Using our velocity function based upon easily defined parameters of absolute depth and total basin depth allowed us to extrapolate the data from the Imperial Valley into the Coachella and Mexicali valleys.

Five of the petroleum wells with velocity data from sonic logging were located in regions with total basin depths between 4000 and $4500 \mathrm{~m}$. Analysis of the velocity versus depth plots for each of these wells (Borchard A-3, East Highline Unit \#1, Mesa \#8-1, Sardi \#1, and Salton Trough Prospect "U.S.A." \#27-1) revealed that they share a similar linear trend of velocity increasing with depth (Fig. 5). This indicates a uniform velocity-depth profile at locations throughout the Imperial Valley with a similar basin depth. A linear regression was calculated for the data from these five sonic logs. At an average total basin depth of $4250 \mathrm{~m}$, velocity $(V)$ $(\mathrm{m} / \mathrm{sec})$ was determined as a function of depth to be 

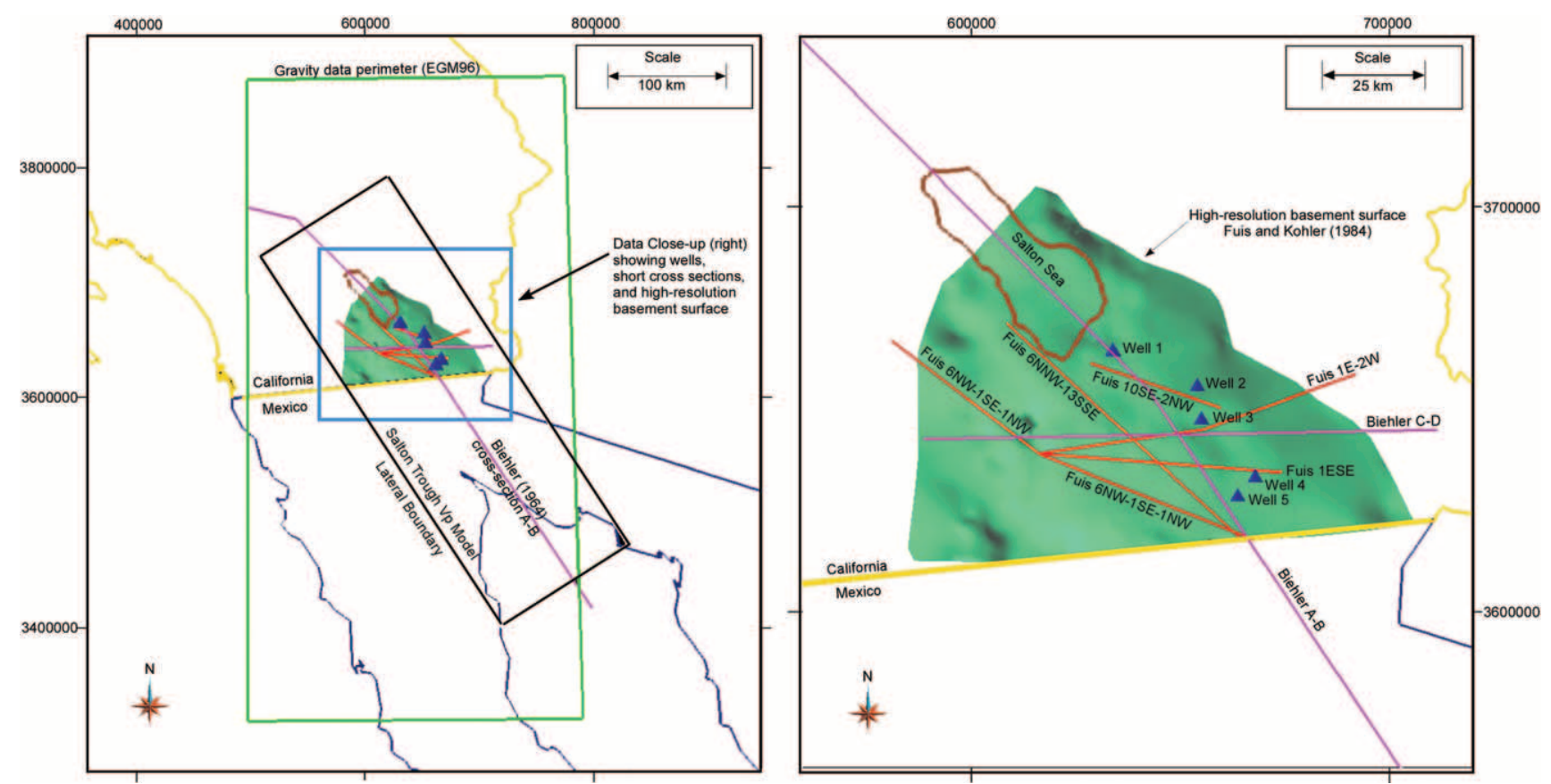

Figure 3. A map view illustrating the locations and extents of the data used in the construction of the Salton Trough $P$-wave velocity model. The image on the right is a close-up of the red box in the left-hand image. Purple lines labeled "Biehler" represent seismic refraction profiles from Biehler (1964). Red lines labeled "Fuis" represent seismic refraction profiles from Fuis et al. (1984). The green surface represents the crystalline basement surface (CBS) as defined by Fuis and Kohler (1984). Key to wells: Well 1, Sardi \#1; Well 2, East Highline Unit \#1; Well 3, Borchard A-3; Well 4, Salton Trough Prospect "U.S.A." 27-1; Well 5, Mesa \#8-1.

$$
V=1.094 z+1160
$$

where $z$ represents absolute depth in meters. The regression has an $R^{2}$ value equal to 0.80 . Note that a velocity-axis intercept $(z=0)$ of $1160 \mathrm{~m} \mathrm{sec}^{-1}$ was determined from the best-fitting linear regression calculated for the well data. This intercept would yield values that are probably too low to accurately represent $P$-wave velocity in the consolidated near-surface sediments, which are about $1600 \mathrm{~m} \mathrm{sec}^{-1}$ based on analyses in other basins (Süss and Shaw, 2003). Thus, in our model we eventually corrected shallow velocity structure by setting a minimum $P$-velocity threshold of $1600 \mathrm{~m} \mathrm{sec}^{-1}$. Nevertheless, the linear velocity gradients we derived in the analysis seem to accurately represent deeper velocity structure and thus were employed to parameterize our velocity model.

Having determined the relation between $P$-wave velocity and absolute depth for one total depth range of the sedimentary basin, we were left to determine how this function varies with the total depth of the sedimentary basin. Isovelocity surfaces were created by interpolation between the lines of constant velocity defined by the seismic refraction study of Fuis et al. (1984). A point set was then created from the nodes defining these surfaces. The points were then sorted and binned by total basin depth in 250-m-depth increments. Twenty-three bins were created, accommodating basin depths from 0 to $5750 \mathrm{~m}$. Velocity was then plotted versus depth for each of these bins, and linear regressions were calculated. These regressions were then used to calculate the gradient of velocity with depth for the total basin depth of their respective bins. Velocity gradients were then plotted versus total basin depth (Fig. 6). Observing a general linear correlation between total sedimentary basin depth and velocity gradient with depth, a linear regression of velocity gradient was calculated for this plot. The following function was determined relating velocity gradient to basin depth:

$$
G=2.17-0.0002588 D,
$$

where $G$ represents velocity gradient versus depth with the units $\sec ^{-1}$ and $D$ equals total sedimentary basin depth. This regression has a $R^{2}$ value of 0.94 .

The velocity gradient predicted by this equation for a total basin depth of $4250 \mathrm{~m}$ is $-1.07 \mathrm{sec}^{-1}$, quite similar to the value of $-1.094 \mathrm{sec}^{-1}$ predicted by the plot of wells at this basin depth. This similarity between velocity gradients predicted by two independent methods gives credibility to the binning method used to calculate the dependence of velocity gradient on sedimentary basin depth. Because sonic log data is accepted as more accurate than velocities obtained from seismic refraction profiles, particularly after the interpolation involved in creation of the isovelocity surfaces, the 


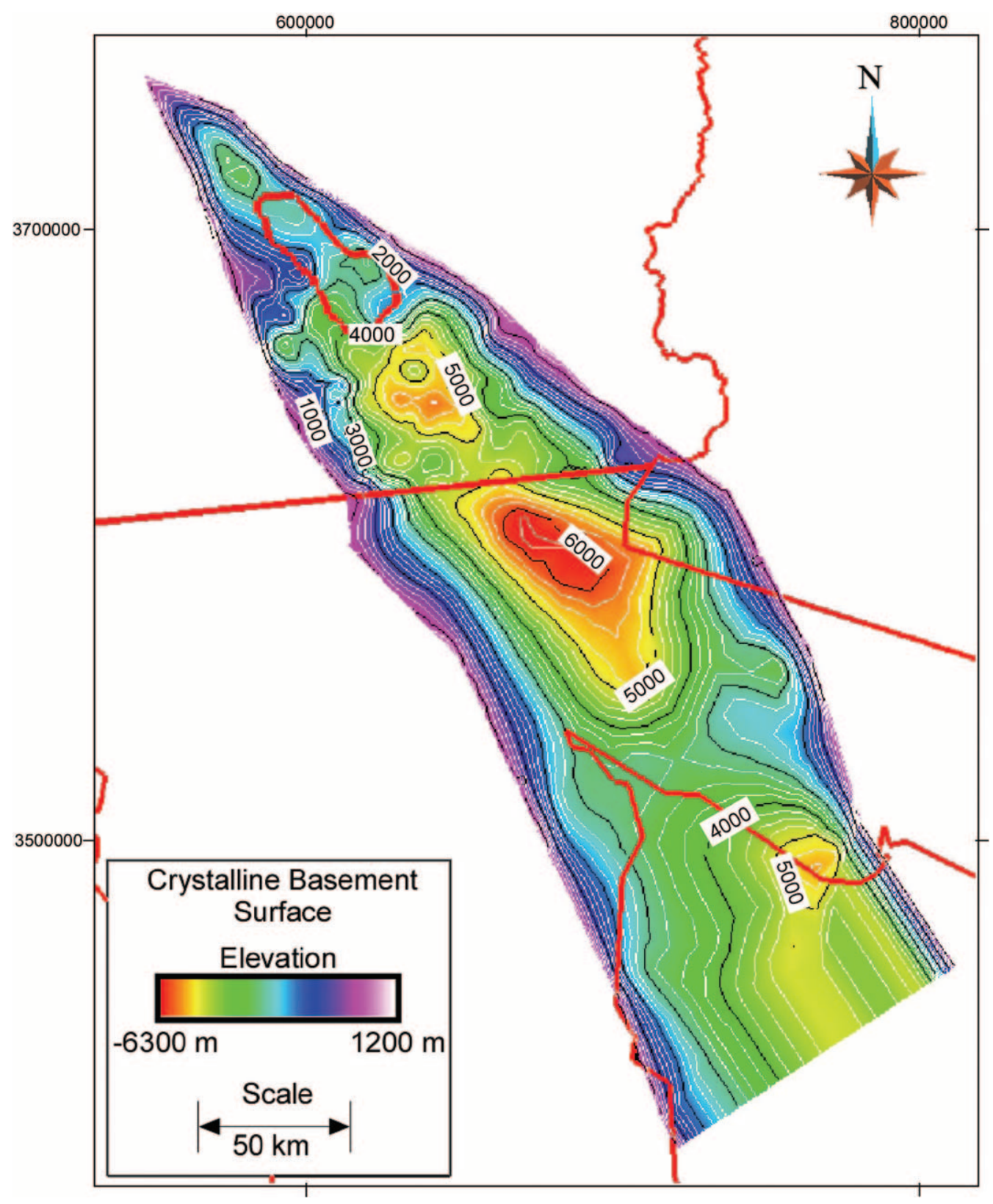

Figure 4. Structure contour map of the top of crystalline basement (CBS) used in our model. The basement surface is based on the map provided by Fuis and Kohler (1984), which was modified and extended using regional gravity data (Lovely, 2005). This surface defines the lower boundary of the sedimentary basin and, thus, the limit of our $P$-wave velocity model. Black contour values are $1000 \mathrm{~m}$, and white contours are $250 \mathrm{~m}$.

constant in equation (2) was calibrated slightly to yield a velocity gradient with depth of $-1.09 \mathrm{sec}^{-1}$ at $4250 \mathrm{~m}$ depth, giving the following equation:

$$
G=2.19-0.0002588 D
$$

Equation (3) was then substituted into equation (1) for the velocity gradient value, yielding the relation:

$$
V=(2.19-0.0002588 D) z+1160 .
$$

This linear function of absolute depth $(z)$ and total sedimentary basin depth $(D)$, both in meters, was then used to define velocity values in meters per sec throughout the Salton Trough sedimentary basin.

Three-Dimensional Model Construction

A GoCAD (Mallet, 1992) voxet, a three-dimensional (3D) orthogonal, spatial array of data cells, was used to pro- 


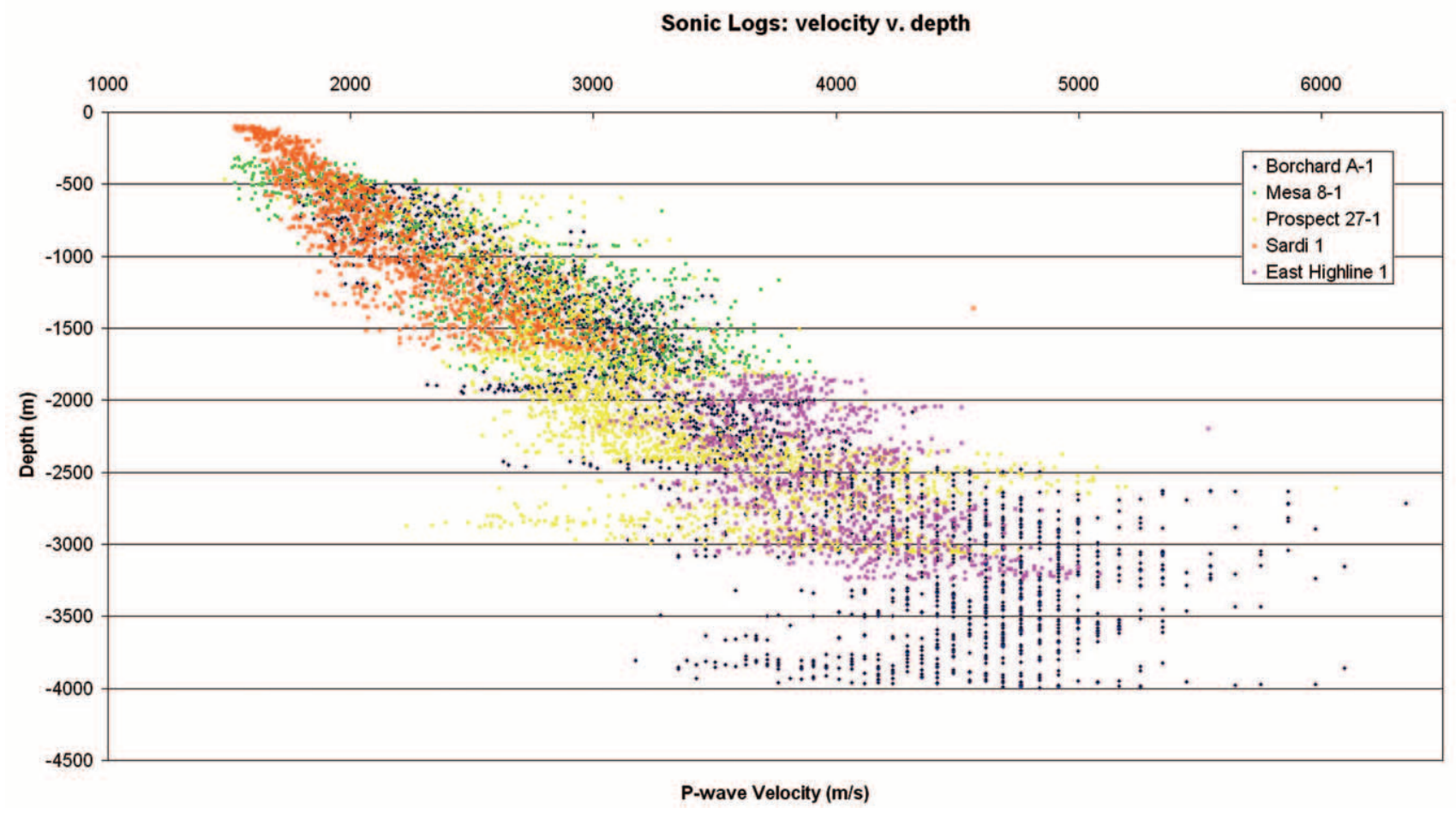

Figure 5. Velocity $\left(V_{\mathrm{P}}\right)$ versus depth plot showing digitized sonic log data from each of the five wells in the Salton Trough

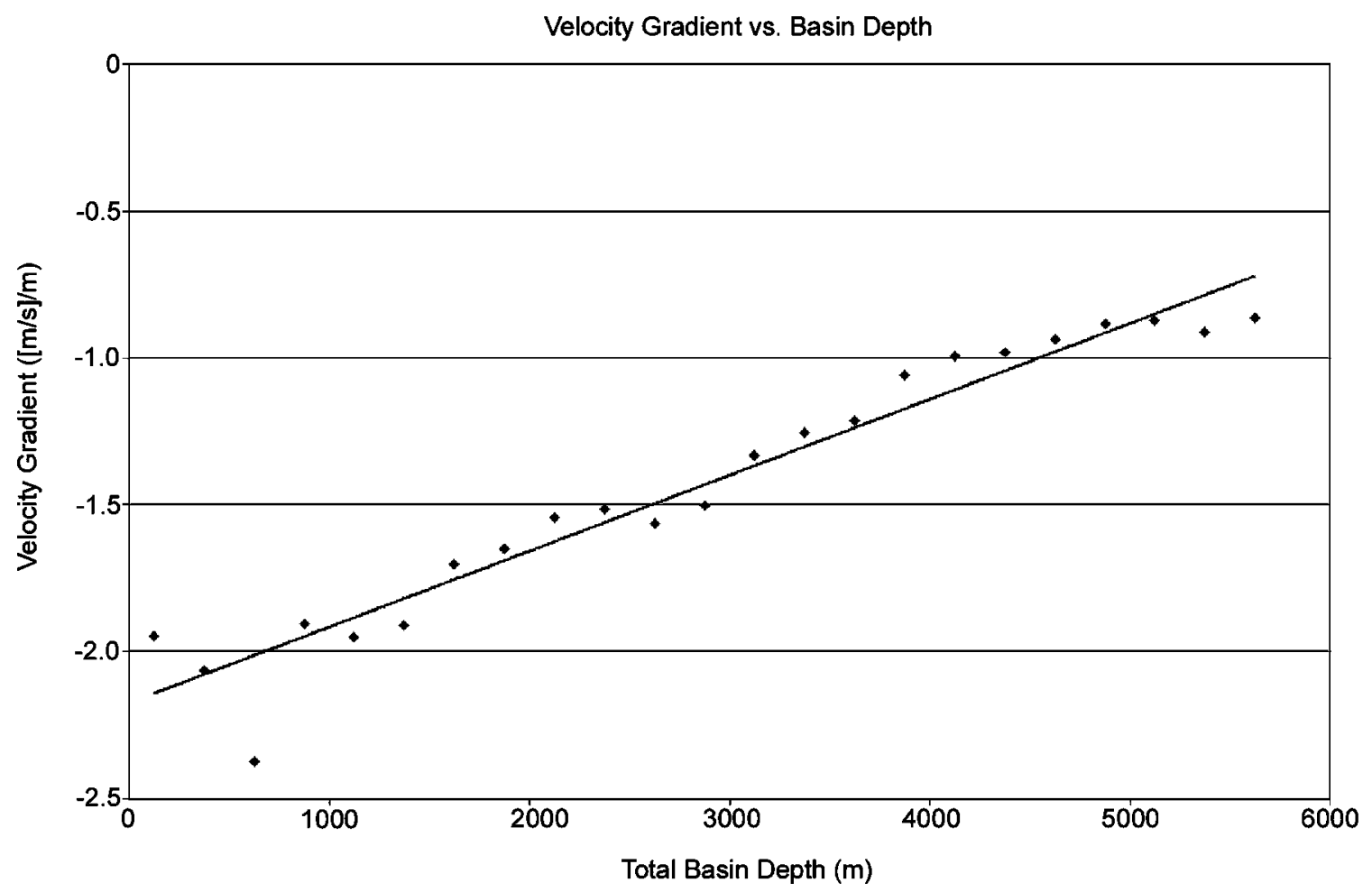

Figure 6. Plot of the velocity gradient calculated for each basin depth interval versus the average total basin depth for that bin. A regression was calculated for this data producing the relation $G=0.0002588(D-2.17)$, which defines the velocity gradient $(G)$ with depth for any basin depth. As explained in the text, this relation was calibrated using borehole sonic logs and used to define the velocity gradient with depth in the final Salton Trough $P$-wave velocity model. 
duce and represent the Salton Trough $P$-wave velocity model. The voxet boundaries include the entire basement surface and are defined by a $383-\mathrm{km}$ axis oriented $33.1^{\circ}$ west of north, a $131 \mathrm{~km}$ axis oriented $56.9^{\circ}$ east of north, a 7.6$\mathrm{km}$ vertical axis, and an origin located at universal transverse mercator (UTM) coordinates $720844,3401799,-6354$ in the North American datum (NAD) 27 North, zone 11, Clark 1866 geoid reference frame. The voxet cell size was $200 \mathrm{~m}$ by $200 \mathrm{~m}$ in the horizontal plane with 100 -m vertical size.

A $P$-wave velocity value for each cell was calculated using equation (4) within the lateral bounds of, and above, the basement surface. No-data-values were applied to cells in all other regions of the voxet, below or beyond the lateral extent of the crystalline basement surface (CBS). All velocity values less than $1600 \mathrm{~m} / \mathrm{sec}$ were then set equal to $1600 \mathrm{~m} /$ sec, a value generally accepted as a minimum $P$-wave velocity for consolidated basin sediments (Süss and Shaw, 2003). Topography was considered in the computational mesh and simulations, but not directly in the velocity voxet. Rather, the computational mesh incorporates topography and samples the velocity voxet only below this surface. This was done because it simplified implementation of the model into the computational mesh used for SEM wave propagation and ground-motion simulations.

Figure 7 shows several cross sections of the final $P$ wave velocity model. These images clearly demonstrate the trends of increasing velocity with depth and upward sloping isovelocity surfaces near the basin edges, as evidenced in sonic logs and seismic refraction data (Biehler, 1964 Fuis et al., 1984) Three-dimensional visual analysis confirmed that modeled $P$-wave velocity values throughout the region correspond well to all available data.

A script was adapted from that produced to deliver the original Harvard velocity model, produced by Süss and Shaw (2003), which accepts coordinates projected in the UTM NAD27 North, zone 11, Clark 1866 geoid or in geographic coordinates (depth in meters). The script also calculates $S$-wave and density values using empirical relations defined in the Los Angeles basin. As described by Komatitsch et al. (2004), $S$-wave speeds are calculated by dividing $P$-wave speeds by a constant that varies linearly from 1.732 in the deepest parts of the basin to 2.0 in shallow sediments. These end members are derived from a Poisson ratio of 0.25 at a depth of $8.5 \mathrm{~km}$ and a Poisson ratio of 0.33 at the surface. Density is defined by the relationship $\rho=\left(V_{\mathrm{p}}\right) / 3+1280$ (McCulloh, 1960; Stidham et al., 2001), a function derived from well data in which $\rho$ represents density $\left(\mathrm{kg} \mathrm{m}^{-3}\right)$ and $V_{\mathrm{p}}$ represents $P$-wave velocity $\left(\mathrm{m} \mathrm{sec}^{-1}\right.$ ). A minimum density of $2000 \mathrm{~kg} \mathrm{~m}^{-3}$ was imposed.

Our new Salton Trough model is incorporated into the latest release of the Southern California Earthquake Center's Community Velocity Model (Harvard), termed CVM-H 4.0
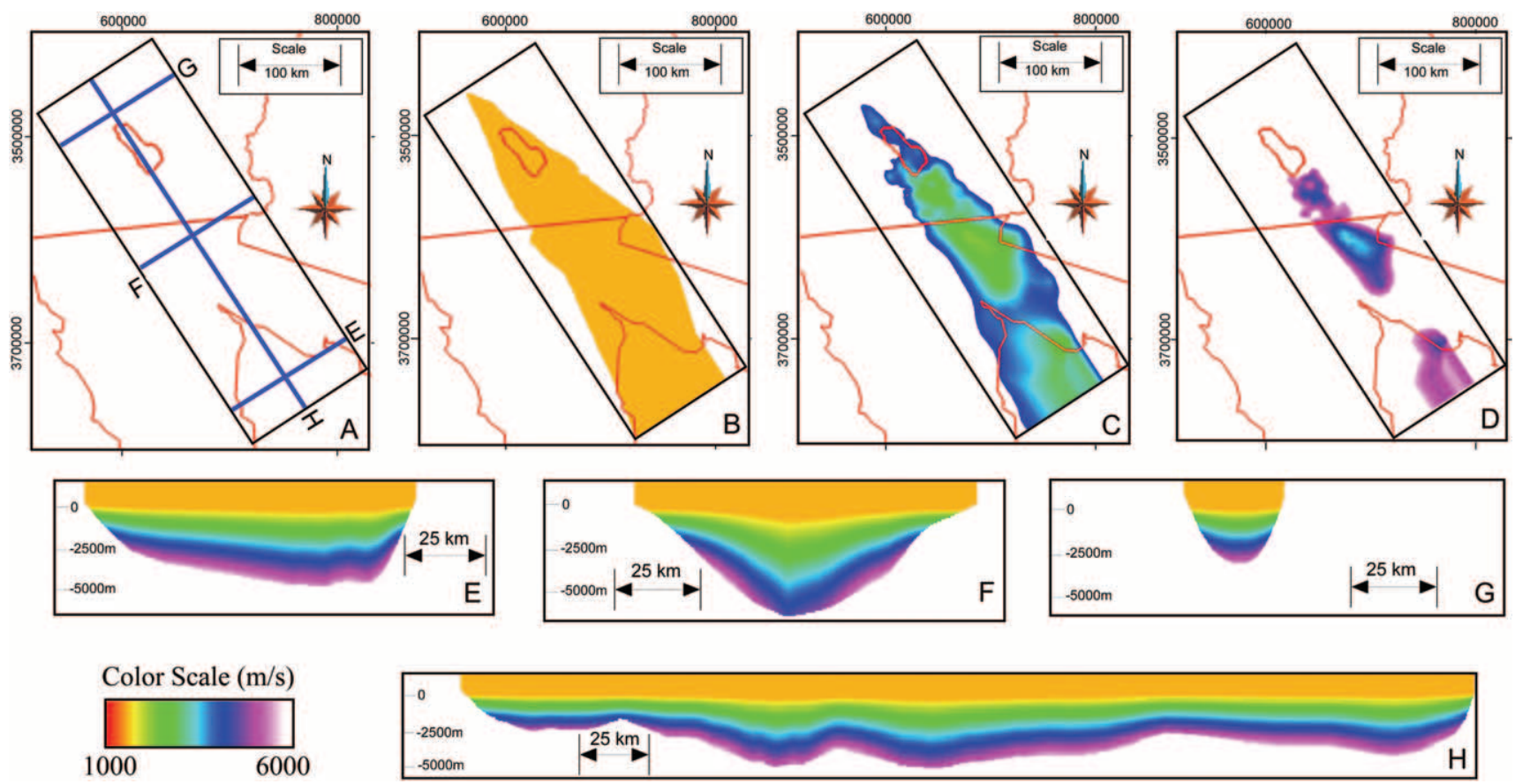

Figure 7. Selected views of the Salton Trough model with $P$-wave velocity values. The black rectangles represent the lateral extent of our rectilinear model, and the white regions within represent crystalline basement rock outside the sedimentary basin model. Key: A, map view illustrating the locations of vertical profiles $\mathrm{E}, \mathrm{F}, \mathrm{G}$, and $\mathrm{H}$; B, horizontal profile at $z=0 ; \mathrm{C}$, horizontal profile at $z=-2060 \mathrm{~m} ; \mathrm{D}$, horizontal profile at $z=-4310 \mathrm{~m}$. Vertical profiles $\mathrm{E}, \mathrm{F}, \mathrm{G}$, and $\mathrm{H}$ are shown with 5 times vertical exaggeration. 
(Süss et al., 2005), which is available through the Center's website (www.scec.org).

Integrating the Salton Trough $P$-Wave Velocity Model into the SEM Computational Mesh

The new Salton Trough $P$-wave velocity model was integrated into the 3D computational mesh used for SEM wave propagation and ground-motion simulations. These simulations were performed on the Dell cluster at the California Institute of Technology Seismological Laboratory. The computational mesh geometry was not modified to accommodate the newly defind CBS in the Salton Trough; rather, the existing mesh was reparameterized using the new basin model. However, the basin shape is incorporated in the computational model by limiting the reparameterization to nodes above our basement surface. This geometric simplification in the mesh was thought to have little impact on the simulation results because of the relatively shallow nature of the Salton basin (6000 m as compared to depths greater than $9000 \mathrm{~m}$ in the Los Angeles Basin) and the relatively gentle topography of the basement surface.

The SEM has been used extensively to simulate seismicwave propagation on regional scales (Komatitsch et al., 2004; Liu et al., 2004). The method combines the geometric flexibility of the finite-element method with an accurate representation of the wave field in terms of high-degree Lagrange polynomials. It is straightforward to incorporate surface topography and bathymetry, as well as topography on any internal discontinuities, into the spectral-element mesh. Because of the use of Lagrange polynomials and GaussLobatto-Legendre quadrature, the mass matrix is exactly diagonal, which makes it relatively simple to implement the method on parallel computers (Komatitsch et al., 2003). Attenuation is accommodated by introducing memory variables (Komatitsch and Tromp, 1999). We use a constant shear quality factor of 90 within the basin and no attenuation elsewhere (Komatitsch et al. 2004). Our calculation of synthetics for earthquakes in southern California is based upon this method, which is described in detail by Komatitsch et al. (2004). The combination of a detailed crustal model and a very accurate numerical technique results in generally good fits between data and synthetic seismograms on all three components of most stations in the SCSN network at periods of $6 \mathrm{sec}$ and longer.

\section{Simulation Results}

\section{November $2002 M_{\mathrm{w}} 4.2$ Yorba Linda Earthquake}

The 3 November $2002 M_{\mathrm{w}} 4.2$ Yorba Linda earthquake was used as a benchmark standard for the new 3D Salton Trough $P$-wave velocity model. This event was chosen because it was used by Komatitsch et al. (2004) in their simulations, allowing us to readily identify the influence of the new basin model on simulation results. Additionally, in SEM calculations small sources such as this can be represented easily and accurately as point sources. Figure 8 presents transverse component displacement seismograms throughout the Salton Trough north of the U.S.-Mexico border produced with the final Salton Trough $P$-wave velocity model and those from the original simulations by Komatitsch et al. (2004), which lacked a detailed representation of the Salton Trough sedimentary basin.

The quality of simulation results using our model was substantially improved over the results of Komatitsch et al. (2004). Specifically, improvement is obvious in the quality of matches between synthetic and measured waveforms at stations CTC, SSW, and BTC. Only stations NSS and WES show noteworthy mismatches of large amplitude shaking. Station NSS exhibits slight overamplification of ground motion, as well as an inappropriately short duration beyond the first two wave peaks. Perhaps these differences could be a result of local site effects not properly represented in our model or effects of our inability to represent local heterogeneities in near-surface velocity. Simulated waveforms at station WES are also poor in simulations with the new model. While the recorded seismograms from the event demonstrate basin amplification effects, simulated waveforms exhibit the dampened signature of stations on crystalline basement, despite the approximately $3000 \mathrm{~m}$ of sediment represented below this station in the model. It is possible that this error results from inaccuracies in our model or computational complexity due to the incidence angle of waves reaching the basin at this station, roughly parallel to the nearby basin edge. Despite these two poorly fit stations, overall results produced with the new Salton Trough $P$-wave velocity model are of good quality and should provide significant improvement in the quality of strong ground motion simulations and seismic hazard assessment in the region.

Hypothetical Major Rupture on the Southern San Andreas Fault

In order to further assess the influence of the new basin model on seismic hazard in the Salton Trough, we simulated a large, plausible earthquake scenario on the southern San Andreas fault, which extends into the basin. Paleoseismic data suggests that the fault, south of the 1857 rupture, breaks in large events that occur, on average, with a repeat time of about two hundred years. However, the fault has not ruptured since about 1680 (Weldon et al., 2005), offering the prospect of a major event that would release this accumulated energy. Similar numerical simulations of hypothetic major earthquakes on the San Andreas fault are the SCEC sponsored TeraShake simulations, which use the finitedifference method to simulate wave propagation on the DataStar supercomputer at the San Diego Supercomputing Center (http://sceclib.sdsc.edu/TeraShake).

We considered a $M_{\mathrm{w}} 7.9$ earthquake along the southern San Andreas fault by mapping the 290-km-long kinematic finite-rupture model with slip distribution and rupture time of the strike-slip portion of the $2002 M_{\mathrm{w}} 7.9$ Denali earth- 

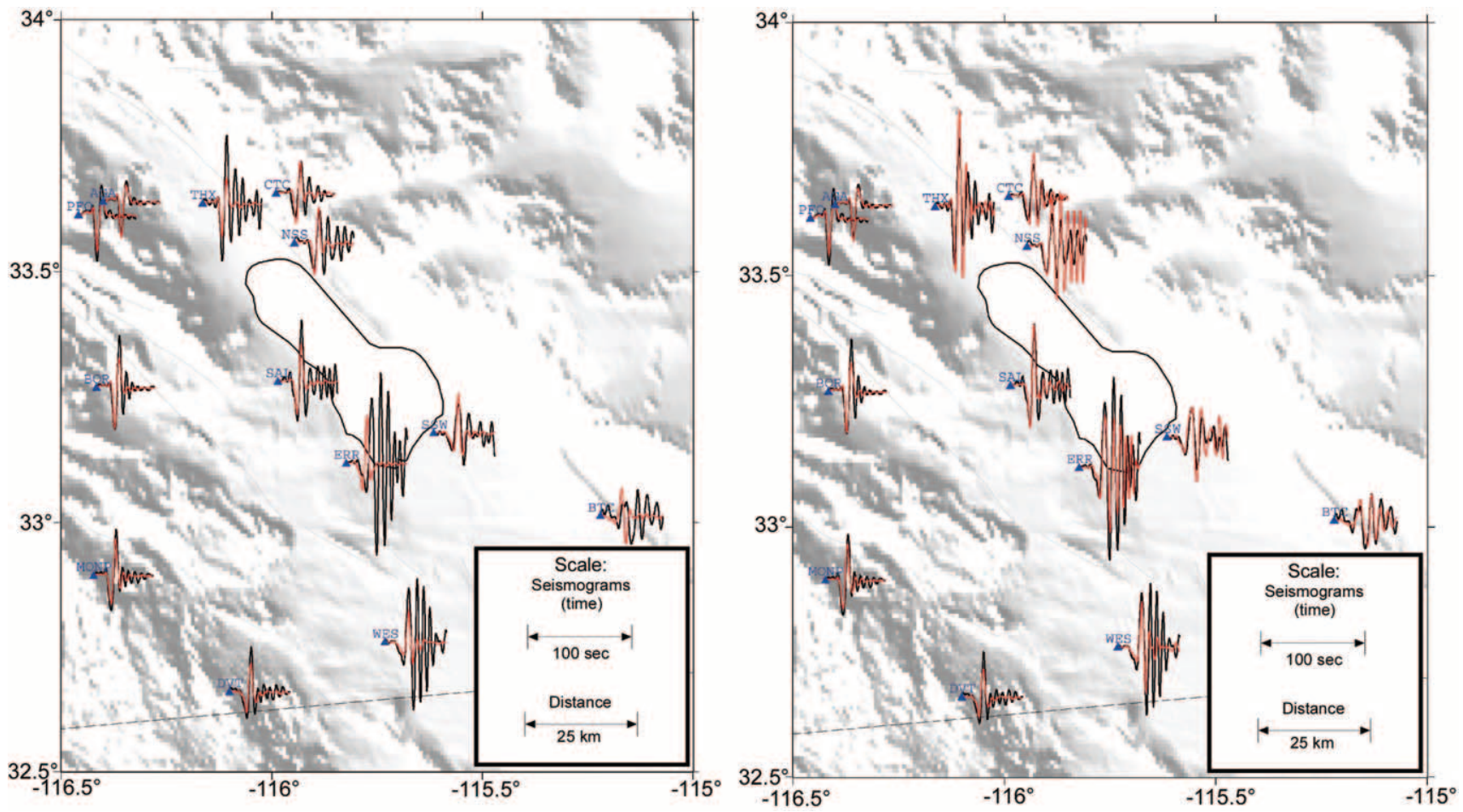

Figure 8. Maps showing transverse component displacement seismograms in and around the Salton Trough from the 3 November $2002 M_{\mathrm{w}} 4.2$ Yorba Linda earthquake. Transverse component seismograms were selected for figures because of the predominantly strike-slip nature of the earthquake. Strike-slip events excite the greatest energy on the transverse component. Black waveforms represent the recorded data, and red waveforms represent the synthetic simulations. The left plot shows simulations using the Los Angeles Basin high-resolution velocity model (Süss and Shaw, 2003) embedded in a regional tomography model (Hauksson, 2000) after Komatitsch et al. (2004), whereas the right plot shows simulations incorporating the new Salton Trough velocity model. The two figures illustrate the improved accuracy of ground-motion simulations produced with the new velocity model. Both the data and the synthetic seismograms were subsequently bandpass filtered between 6 and $35 \mathrm{sec}$ with a four-pole two-pass butterworth filter. Note that stations AGA, PFQ, BQR, MONP, and DVT are located on hard rock, outside the sedimentary basin and are thus not significantly impacted by our new model.

quake (Tsuboi et al., 2003) onto a simplified representation of the San Andreas fault derived from the Southern California Earthquake Center (SCEC)'s Community Fault Model (Plesch et al., 2003). Figure 9 illustrates several select characteristics of our simulated rupture. The similar strike-slip nature of the San Andreas and the portion of the Denali rupture used in our simulation, as well as their similar geometries, makes the Denali solution a reasonable choice for a hypothetical major rupture of such large magnitude on the southern San Andreas. This rupture model would certainly be a most threatening scenario for the Salton Trough and appears credible based on the paleoseismic record (Weldon et al., 2005).

Our rupture length estimate is a plausible scenario based on paleoseismological trench studies compiled and analyzed by Weldon, et al. (2004). The magnitude of our simulation is consistent with this paleoseismic data on the southern segment of the fault, and comparable to the $1857 M_{\mathrm{w}} 7.9$ Fort
Tejon earthquake, which ruptured an adjacent, northern segment of the fault extending from Parkfield south through the San Gabriel Mountains. The rupture initiation, location, and direction of propagation cannot be predicted based upon our current understanding of tectonics and fault behavior. Because a north-to-south rupture would focus more energy into the Salton Trough, we selected such a rupture for our simulation.

In Figure 10, a series of images showing horizontal ground motion throughout the event clearly illustrates the effects of basin resonance and the focusing of wavefronts resulting from low seismic velocities and basin shape in the Salton Trough. Results of our simulation are accurate at periods of $3 \mathrm{sec}$ and longer. At 22 and $44 \mathrm{sec}$, the wavefronts take on the elongated circular shape typical of a propagating rupture. At $81.4 \mathrm{sec}$, and moreso at $112.2 \mathrm{sec}$, the effects of the low-velocity sediments are clear as the wavefronts curl backward in the Salton Trough. The frames illustrating 143 

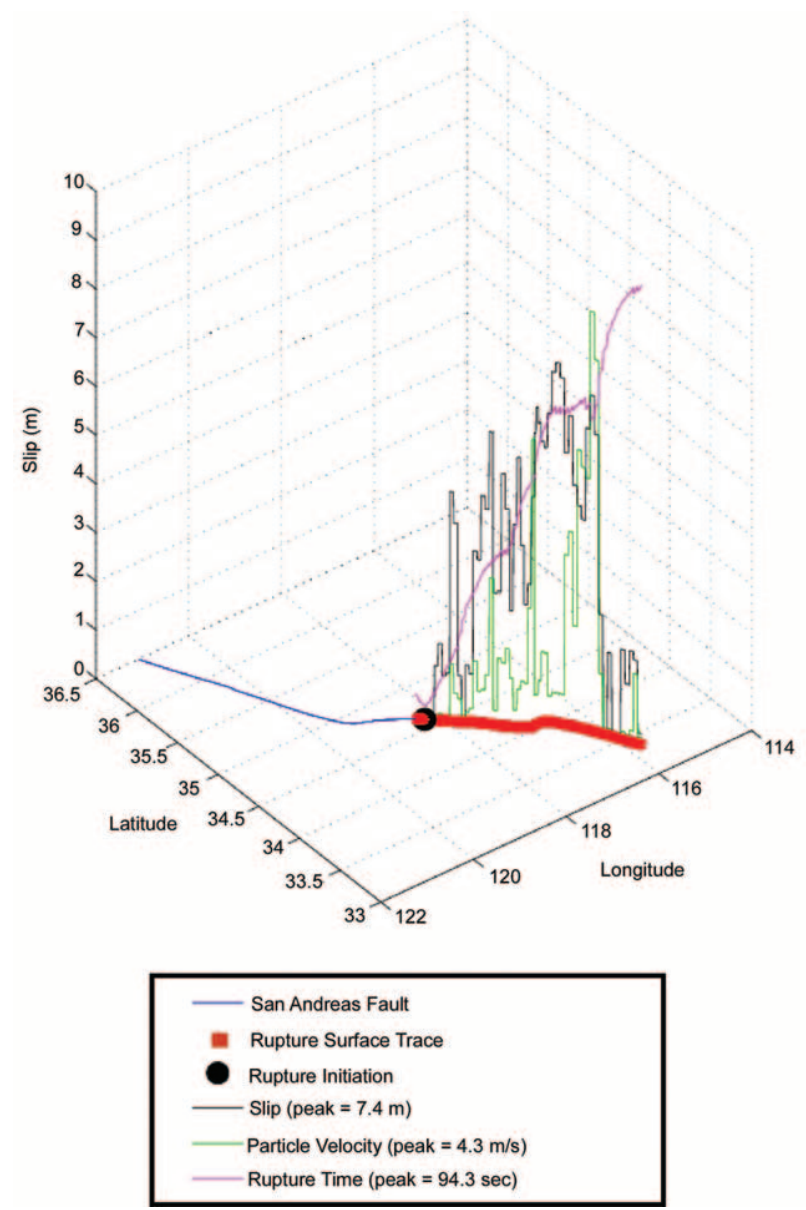

Figure 9. Plot of the kinematic finite fault rupture model used for our hypothetical $M_{\mathrm{w}} 7.9$ event on the San Andreas fault.

and $176 \mathrm{sec}$ demonstrate the effects of resonance, with significant ground motion persisting throughout the sedimentary basin after energy has dissipated elsewhere. The jumbled and somewhat indistinguishable wavefronts in these frames illustrate the complexity and persistence of ground motion in the sedimentary basin. In combination with the amplification of ground motion (Fig. 11), the persistence of energy due to low velocities and resonance may increase the potential for structural damage to buildings located within the sedimentary basin.

Figure 11 shows shakemaps illustrating peak ground velocity and acceleration resulting from this hypothetical event. The shakemaps dramatically illustrate the amplification of peak velocity and acceleration due to sedimentary rocks in the Salton Trough, with velocity and acceleration values at least 3 and, in many regions, 5 or more times the amplitude of values along the rupture trace to the north on crystalline basement rocks. These simulated velocity and acceleration values in the basin are quite large, and a direct result of the new basin velocity description. The regions of greatest peak velocity and acceleration (red and yellow in Fig. 11) outline the geometry of the sedimentary basin in the
Coachella and northern Imperial valleys, further emphasizing the impact of low-velocity sediments on ground-motion amplification.

The quantitative prediction of ground motion provided by our new model allows more accurate assessment of the potential damage from such a catastrophic earthquake. Forecast damage due to seismic activity is typically calculated as a function of the magnitude of surface velocity and acceleration, which our model and simulations provide, and on population density and construction quality. In our large earthquake simulation, the most intense ground motion occurs in the Coachella Valley and the region immediately around the Salton Sea, with widespread surface velocities exceeding $0.15 \mathrm{~m} \mathrm{sec}^{-1}$ and acceleration exceeding $0.2 \mathrm{~m}$ $\mathrm{sec}^{-2}$. In comparison, localized peak values predicted on the fault are $3.8 \mathrm{~m} \mathrm{sec}^{-1}$ and $4.3 \mathrm{~m} \mathrm{sec}^{-2}$. This magnitude of ground shaking suggests the prospect for significant damage to many, if not most, buildings and structures (Krinitzsky and Chang, 1988). The city of Indio is located at the heart of the region prone to basin amplification effects. Palm Springs, to the north, would suffer peak surface velocities on the order of $0.1 \mathrm{~m} \mathrm{sec}^{-1}$, and Brawley and El Centro, to the south, would witness peak velocities exceeding $0.1 \mathrm{~m}$ $\mathrm{sec}^{-1}$. Eighty kilometers south of our simulated rupture termination, across the Mexican border, the city of Mexicali could suffer significant ground shaking as well. The ground motions predicted in the southern portion of the trough, including the communities of Brawley, El Centro, and Mexicali, are comparable to those predicted by the TeraShake project (Minster et al., 2004). The peak velocity values predicted along the fault by our simulation are nearly three times the magnitude of peak velocities produced by the 1994 Northridge earthquake (peak velocities at Northridge were approximately $1.20 \mathrm{~m} \mathrm{sec}^{-1}$ ) (Wald, 1999; Wald et al., 2000), which resulted in over $\$ 40$ billion in damages and 57 deaths north of Los Angeles. The area in the Salton Trough affected by amplified surface velocity values is also much larger than in the Northridge event. The vast area affected by these peak surface velocity and acceleration values and the predicted amplitudes emphasize that a major rupture on the southern San Andreas fault could cause substantial damage to the populated areas of the Salton Trough.

\section{Conclusions}

This study presents a new 3D $P$-wave velocity model of the Salton Trough sedimentary basin based on seismic refraction profiles (Fuis and Kohler, 1984; Fuis et al., 1984) and sonic log data from petroleum wells. This model was implemented into a computational mesh used for SEM wave propagation and strong ground motion simulations (Komatitsch et al., 2004). Simulations of the 3 November $2002 M_{\mathrm{w}}$ 4.2 Yorba Linda earthquake demonstrated that the new sedimentary basin velocity model allowed accurate quantitative prediction of ground motion from a defined source. We then performed simulations of a hypothetical $M_{\mathrm{w}} 7.9$ earthquake 

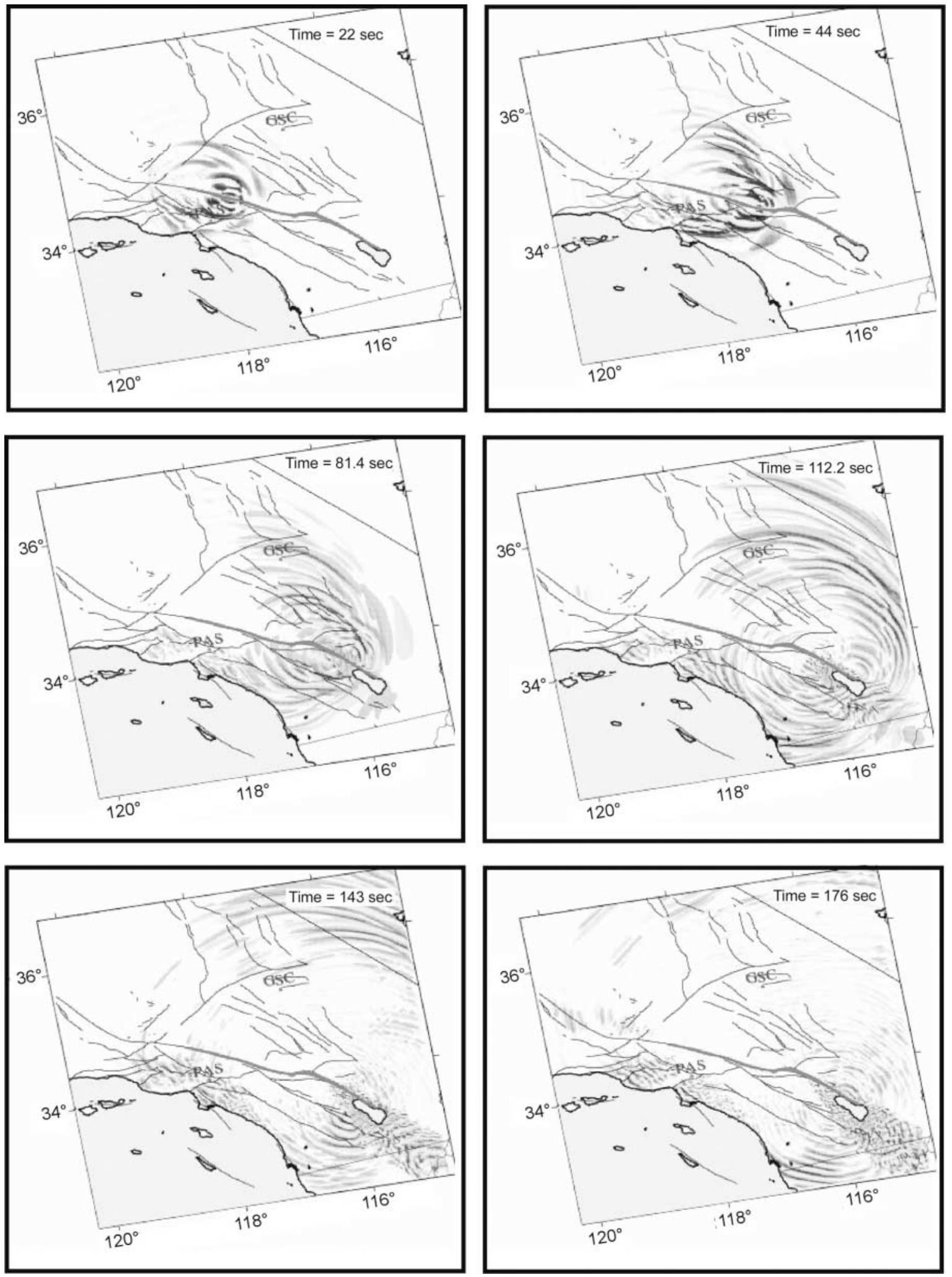

Figure 10. Time windows of the horizontal velocity during the hypothetical $M_{\mathrm{w}}$ 7.9 event on the southern San Andreas fault. Note the deceleration of wave propagation when energy reaches the Salton Trough ( $81.4 \mathrm{sec}$ onward). Moreover, note the extended duration of intense ground motion in the trough, which outlines the basin shape. 

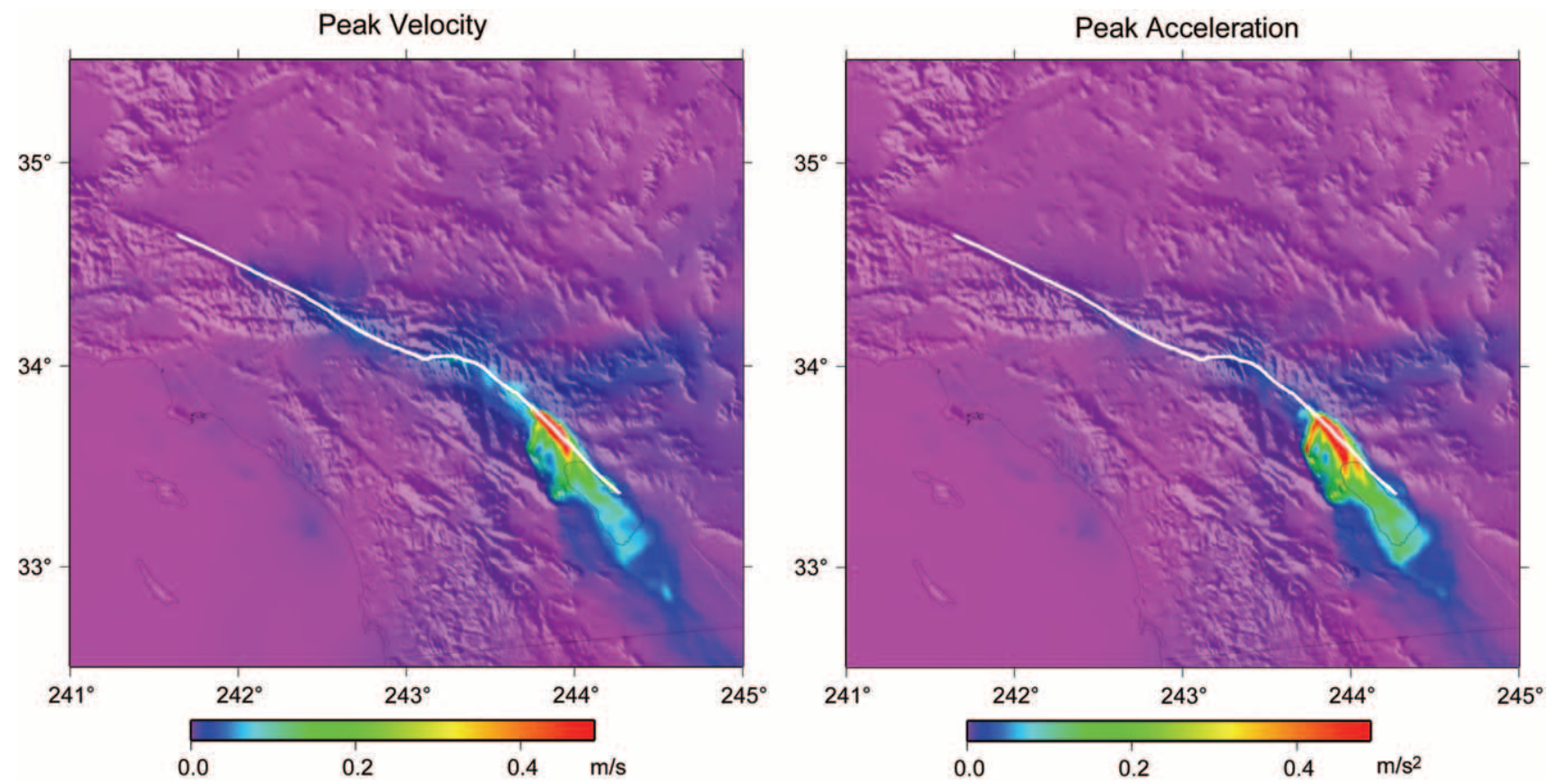

Figure 11. Maps showing peak ground velocity (left) and acceleration (right) from a simulated, hypothetical $M_{\mathrm{w}} 7.9$ rupture along the southern San Andreas fault. The surface trace of the rupture is shown in white. The rupture initiated at the northern end of this trace and propagated southward. Note the large peak velocity and acceleration values in the Salton Trough resulting from wave amplification due to low seismic velocities in the sedimentary basin. The magnitude and extent of amplification suggest great potential for damage in the Salton Trough. The synthetics used in the calculation of these PGV and PGA maps were low-pass filtered with a corner at $3 \mathrm{~s}$.

on the southern San Andreas fault to estimate the ground shaking hazard in the Salton Trough region. The results of this simulation show large amounts of basin amplification, particularly in the northern part of the Salton Trough, as reflected in ground velocities and accelerations of $3.8 \mathrm{~m} \mathrm{sec}$ and $4.3 \mathrm{~m} \mathrm{sec}^{-2}$, respectively, close to the fault, and $0.15 \mathrm{~m}$ sec and $0.2 \mathrm{~m} \mathrm{sec}^{-2}$, respectively, immediately around the Salton Sea. Thus, an earthquake of this magnitude, amplified by a deep sedimentary basin, would likely produce intense and widespread damage over a very large region.

Ultimately, the enhanced ability to quantitatively predict ground motion from any earthquake source based on the new basin model should offer assistance in more accurately quantifying regional earthquake hazards and mitigating risks.

\section{Acknowledgments}

The authors would like to thank Chen Ji for mapping the Denali CMT solution onto the San Andreas, M. Peter Süss for providing the original C code to deliver Harvard Los Angeles Basin velocity model, Andreas Plesch for modifying the code to deliver the Salton Trough model and for his assistance throughout this project, Chris Guzofski and George Planansky for technical assistance throughout and revisions of the manuscript, and the Harvard Structural Geology group for valuable discussion. They would also like to thank James Rice, Pengcheng Liu, and an anonymous reviewer for constructive reviews. The spectralelement simulations presented in this article were performed on Caltech's Division of Geological and Planetary Sciences Dell cluster. This research was supported by the Southern California Earthquake Center (SCEC), which is funded by NSF Cooperative Agreement EAR-0106924 and USGS Cooperative Agreement 02HQAG0008. The SCEC Contribution Number for this article is 976 .

\section{References}

Aagaard, B. T., J. F. Hall, and T. H. Heaton (2001). Characterization of near-source ground motions with earthquake simulations, Earthquake Spectra 17, no. 2, 177-207.

Antolik, M., S. Larsen, D. Dreger, and B. Romanowicz (1996). Modeling broadband waveforms in central California using finite differences, Seism. Res. Lett. 67, 30.

Bao, H., J. Bielak, O. Ghattas, L. F. Kallivokas, D. R. O'Hallaron, J. R. Shewchuk, and J. Xu (1998). Large-scale simulation of elastic wave propagation in heterogeneous media on parallel computers, Computat. Meth. Appl. Mech. Eng. 152, 85-102.

Biehler, S. (1964). Geophysical study of the salton trough of southern California, Ph.D. Thesis, California Institute of Technology, Pasadena, 139 pp.

Bielak, J., J. Xu, and O. Ghattas (1999). Earthquake ground motion and structural response in alluvial valleys, J. Geotech. Geoenviron. Eng. 125, 413-423.

Boore, D. M. (1972). Finite difference methods for seismic wave propagation in heterogeneous materials, in Methods in Computational Physics, B. A. Bolt (Editor), Vol. 11, Academic, New York.

Borcherdt, R. D. (1994). Synopsis, in The Loma Prieta, California, Earthquake of October 17, 1989: Strong Ground Motion and Ground Failure U.S. Geol. Surv. Profess. Pap. 1551A, A1-A7.

Frankel, A., and W. Leith (1992). Evaluation of topographic effects on $P$ and $S$ waves of explosions at the northern Novaya Zemlya test site using 3-D numerical simulations, Geophys. Res. Lett. 19, 1887-1890. 
Frankel, A., and J. Vidale (1992). A three-dimensional simulation of seismic waves in the Santa Clara valley, California, from the Loma Prieta aftershock, Bull. Seism. Soc. Am. 82, 2045-2074.

Fuis, G. S., and W. M. Kohler (1984). Crustal structure and tectonics of the Imperial Valley region, California, in The Imperial Basin-Tectonics, Sedimentation, and Thermal Aspects, C. Rigsby (Editor), Field Trip Guidebook, Pacific Section SEPM, Society for Sedimentary Geology, Vol. 40, 1-13.

Fuis, G. S., and W. D. Mooney (1991). Lithospheric structure and tectonics from seismic refraction and other data, in The San Andreas Fault System, California, U.S. Geol. Surv. Profess. Pap. 1515, 207-236.

Fuis, G. S., W. D. Mooney, J. H. Healy, G. A. McMechan, and W. J. Lutter (1984). A seismic refraction survey of the Imperial Valley region, California, J. Geophys. Res. 89, no. B6, 1165-1189.

Garatani, K., H. Nakamura, H. Okuda, and G. Yagawa (2000). Large-scale parallel wave propagation analysis by GeoFEM, Lecture Notes in Computational Science 1823, 445-453.

Hauksson, E. (2000). Crustal structure and seismicity distribution adjacent to the Pacific and North America plate boundary in southern California, J. Geophys. Res. 105, 13,875-13,903.

Hill, D. P., J. P. Eaton, and L. M. Jones (1991). Seismicity, 1980-1986, in The San Andreas Fault System, California, U.S. Geol. Surv. Profess. Pap. 1515, 115-151.

Hill, M. L., and T. W. Dibblee, Jr. (1953). San Andreas, Garlock, and Big Pine faults, California: a study of the character, history, and tectonic significance of their displacements, Geol. Soc. Am. Bull. 64, 443-458.

Hruby, C. E., and I. A. Beresnev (2003). Empirical corrections for basin effects in stochastic ground-motion prediction, based on the Los Angeles basin analysis, Bull. Seism. Soc. Am. 93, 1679-1690.

Ji, C., D. V. Helmberger, and D. J. Wald (2000). Basin structure estimation by waveform modeling: forward and inverse methods, Bull. Seism. Soc. Am. 90, 964-976.

Komatitsch, D., and J. Tromp (1999). Introduction to the spectral-element method for 3-D seismic wave propagation, Geophys. J. Int. 139, 806822.

Komatitsch, D., Q. Liu, J. Tromp, P. Süss, C. Stidham, and J. H. Shaw (2004). Simulations of ground motion in the Los Angeles basin based upon the spectral element method, Bull. Seism. Soc. Am. 94, 187-206.

Komatitsch, D., S. Tsuboi, C. Ji, and J. Tromp (2003). A 14.6 billion degrees of freedom, 5 teraflops, 2.5 terabyte earthquake simulation on the Earth Simulator, in Proc. of the ACM/IEEE Supercomputing SC'2003 conference, November 2003, Phoenix, Arizona (CD-ROM).

Krinitzsky, E. L., and F. K. Chang (1988). Intensity-related earthquake ground motions, Bull. Assoc. Eng. Geol. 25, 425-435.

Kristek, J., P. Moczo, K. Irikura, T. Iwata, and H. Sekiguchi (1999). The 1995 Kobe mainshock simulated by 3D finite differences, in The Effects of Surface Geology on Seismic Motion, K. Irikura, K. Kudo, H. Okada, and T. Sasatani (Editors), Vol. 3, Balkema, Rotterdam, The Netherlands, 1361-1368.

Lachenbruch, A. H., J. H. Sass, and S. P. Galanis, Jr. (1985). Heat flow in southernmost California and the origin of the Salton Trough, J. Geophys. Res. 90, no. B8, 6709-6736.

Larsen, S., M. Antolik, D. Dreger, C. Stidham, C. Schultz, A. Lomax, and B. Romanowicz (1997). 3-D models of seismic wave propagation: simulating scenario earthquakes along the Hayward fault, Seism. Res. Lett. 68, 328.

Lemoine, F. G., S. C. Kenyon, J. K. Factor, R. G. Trimmer, N. K. Pavlis, D. S. Chinn, C. M. Cox, S. M. Klosko, S. B. Luthcke, M. H. Torrence, Y. M. Wang, R. G. Williamson, E. C. Pavlis, R. H. Rapp, and T. R. Olson (1998). The Development of the Joint NASA GSFC and NIMA Geopotential Model EGM96, NASA/TP 1998-206861, NASA Goddard Space Flight Center, Greenbelt, Maryland.

Liu, Q., J. Polet, D. Komatitsch, and J. Tromp (2004). Spectral-element moment tensor inversions for earthquakes in southern California, Bull. Seism. Soc. Am. 94, no. 5, 1748-1761.

Lovely, P. (2005). A structural $\left(V_{\mathrm{p}}\right)$ model of the Salton Trough, California, and its implications for strong-ground motion simulations and seismic hazard, A.B. Thesis, Harvard University, 79 pp.

Lysmer, J., and L. A. Drake (1972). A finite element method for seismology, in Methods in Computational Physics, Academic, New York, Vol. 11.

Magistrale, H., S. Day, R. W. Clayton, and R. Graves (2000). The SCEC southern California reference three-dimensional seismic velocity model Version 2, Bull. Seism. Soc. Am. 90, S65-S76.

Mallet, J. L. (1992). Discrete smooth interpolation in geometric modeling, Comput. Aided Design 24, no. 4, 178-191.

McCulloh, T. H. (1960). Gravity variations and the geology of the Los Angeles basin of California, U.S. Geol. Surv. Profess. Pap. 400-B, 320-325.

McLaughlin, K. L., and S. M. Day (1994). 3-D elastic finite-difference seismic wave simulations, Computat Phys. 8, no. 6, 656-663.

Minster, J. B., K. Olson, R. Moore, S. Day, P. Maechling, T. Jordan, M. Faerman, Y. Chui, G. Ely, Y. Hu, B. Shkoller, C. Marcinkovich, J. Bielak, D. Okaya, R. Archuleta, N. Wilkins-Diehr, S. Cutchin, A. Chourasia, G. Kremenek, A. Jagatheesan, L. Brieger, A. Majundar, G. Chukkapalli, Q. Xin, R. Moore, B. Banister, D. Thorp, P. Kovatch, L. Diegel, T. Sherwin, C. Jordan, M. Thiebaux, and J. Lopez (2004). The SCEC TeraShake Earthquake Simulations, EOS Trans. AGU 85, no. 47, Fall Meeting Suppl., Abstract SF31B-05.

Minster, J., K. B. Olsen, R. Moore, S. Day, P. Maechling, T. Jordan, M. Faerman, Y. Cui, G. Ely, Y. Hu, B. Shkoller, C. Marcinkovich, J. Bielak, D. Okaya, R. Archuleta, N. Wilkins-Diehr, S. Cutchin, A. Chourasia, G. Kremenek, A. Jagatheesan, L. Brieger, A. Majundar, G. Chukkapalli, Q. Xin, B. Banister, D. Thorp, P. Kovatch, L. Diegel, T. Sherwin, C. Jordan, M. Thiebaux, and J. Lopez (2004) The SCEC TeraShake Earthquake Simulation, EOS Trans. AGU 85, no. 47, Fall Meet. Suppl., Abstract SF31B-05 INVITED.

Olsen, K. B., J. C. Pechmann, and G. T. Schuster (1995). Simulation of 3-D elastic wave propagation in the Salt Lake basin, Bull. Seism. Soc. Am. 85, 1688-1710.

Paillet, F. R., R. H. Morin, R. E. Hodges, L. C. Robison, S. S. Priest, J. H. Sass, J. D. Hendricks, P. W. Kasameyer, G. A. Pawloski, R. C. Carlson, A. G. Duba, J. R. Hearst, and R. L. Newmark (1986). Preliminary report on geophysical well logging activity on the Salton Sea Scientific Drilling Project, Imperial Valley, California. U.S. Geol. Surv. Open-File Rept. 86-544.

Pitarka, A., and K. Irikura (1996). Modeling 3D surface topography by a finite-difference method: Kobe-JMA station site, Japan, case study, Geophys. Res. Let. 23, 2729-2732.

Plesch, A., J. H. Shaw, and SCEC CFM Working Group (2003). SCEC CFM-A WWW accessible community fault model for Southern California, EOS Trans. AGU 84, S12B-0395.

Rockwell, T., and A. G. Sylvester (1979). Neotectonics of the Salton Trough, in Tectonics of the Juncture between the San Andreas Fault System and the Salton Trough, Southeastern CA: A Guidebook, J. C. Crowell and A. G. Sylvester (Editors), Department of Geological Sciences, University of California, Santa Barbara, 41-52.

Sandwell, D. T., and W. H. F. Smith (1997). Marine gravity anomaly from Geosat and ERS 1 satellite altimetry, J. Geophys. Res. 102, no. B5, 10,039-10,054.

Satoh, T., H. Kawase, T. Sato, and A. Pitarka (2001). Three-dimensional finite-difference waveform modeling of strong motions observed in the Sendai basin, Japan, Bull. Seism. Soc. Am. 91, 365-380.

Schmidt, N. (1990). Plate tectonics and the Gulf of California region, Arizona Geol. 20, 1-4.

Southern California Earthquake Data Center (SCEDC). www.data.scec.org (last accessed).

State of California Department of Finance (2000). Intercensal Estimates of the Population of California: State and Counties 1990-2000, Report I 90-00 July, May 2001, California Statistical Abstract, December 2000.

Stidham, C., M. Antolik, D. Dreger, S. Larsen, and B. Romanowicz (1999). Three-dimensional structure influences on the strong motion wave- 
field of the 1989 Loma Prieta earthquake, Bull. Seism. Soc. Am. 89, 1184-1202.

Stidham, C., M. P. Süss, and J. H. Shaw (2001). 3D density and velocity model of the Los Angeles basin, Geological Society of America 2001 Annual Meeting Abstracts 33, p. 299, Geological Society of America, Denver, Colorado.

Süss, P., and J. H. Shaw (2003). P wave seismic velocity structure derived from sonic logs and industry reflection data in the Los Angeles basin, California, J. Geophys. Res. 108, no B3, doi 10.1029/2001JB001628.

Sylvester, A. G. (1999). Rifting, Transpression, and Neotectonics in the Central Mecca Hills, Salton Trough, California, University of California, Santa Barbara, 52 pp.

Terres, R., and J. C. Crowell (1979). Plate tectonic framework of the San Andreas-Salton Trough juncture, in Tectonics of the Juncture between the San Andreas Fault System and the Salton Trough, Southeastern California: A Guidebook, J. C. Crowell and A. G. Sylvester (Editors), Department of Geological Sciences, University of California, Santa Barbara, 15-25.

Tsuboi, S., D. Komatitsch, C. Ji, and J. Tromp (2003). Broadband modeling of the 2002 Denali fault earthquake on the Earth Simulator, Phys. Earth Planet. Interiors 139, 305-312.

USGS (2000). GTOPO30 data in GRID format. U.S. Geological Survey EROS Data Center (CD-ROM).

Wald, D. (1999). Generation of instrumental ground motion maps, http:// pasadena.wr.usgs.gov/shake/pubs/shake/node3.html (last accessed May 2006).
Wald, D., L. Wald, J. Goltz, B. Worden, and C. Scrivner (2000). "ShakeMaps"-Instant Maps of Earthquake Shaking, Fact Sheet 10300, U.S. Geological Survey, Pasadena, California.

Weldon, R., T. Fumal, and G. Biasi (2004). Wrightwood and the earthquake cycle: what a long recurrence record tells us about how faults work, GSA Today 14, 4-10.

Weldon, R. J., T. E. Fumal, G. Biasi, and K. M. Scharer (2005). Past and future earthquakes on the San Andreas fault, Science 308, 966-967.

Wright, R., E. Griffin, G. Hepner, R. Parrott, A. Winckell, C. Carter, and C. Langevin (1998). The Imperial Valley-Mexicali Interface, http:// geography.sdsu.edu/Research/Projects/Imperial/impweb.html (last accessed May 2005).

Department of Earth and Planetary Sciences

Harvard University

20 Oxford Street

Cambridge, Massachusetts 02138

(P.L., J.H.S.)

Seismological Laboratory

California Institute of Technology

1200 E. California Blvd.

Pasadena, California 91125

(Q.L., J.T.)

Manuscript received 4 August 2005. 